\title{
RESEARCH OF THE SYNGLE CRYSTAL AND MULTILAYER COMPOSITE DETECTORS RESPONSE UNDER IRRADIATION BY FAST NEUTRONS
}

\author{
(D)Volodymyr Ryzhikov', (D)Gennadiy Onyshchenko ${ }^{1,2 *}$, (D) Ivan Yakymenko², \\ (D) Sergei Naydenov ${ }^{1,3}$, Alexandr Opolonin ${ }^{1}$, Sergei Makhota ${ }^{1}$ \\ ${ }^{1}$ Institute for Scintillation Materials, STC "Institute for Single Crystals", National Academy of Sciences of Ukraine \\ 60 Nauky Ave., 61001 Kharkiv, Ukraine \\ ${ }^{2}$ V.N. Karazin Kharkiv National University, 4 Svobody Sq., Kharkiv, 61022, Ukraine \\ ${ }^{3}$ Institute for Single Crystals, STC "Institute for Single Crystals”, National Academy of Sciences of Ukraine \\ 60 Nauky Ave., 61001 Kharkiv, Ukraine \\ *E-mail: gennadiy.m.onyshchenko@karazin.ua \\ Received April 15, 2019; revised May 20, 2019; accepted June 3, 2019
}

\begin{abstract}
The object of this work was to study the response of the detectors based on the oxide scintillators under irradiation by a flux of fast neutrons from ${ }^{239} \mathrm{Pu}$-Be source by counting photomultiplier tube pulses. In the process of the research the counting efficiency of the detectors was measured in units of (pulse $\left.\times \mathrm{s}^{-1} \times \mathrm{cm}^{-2}\right) /\left(\right.$ neutron $\left.\times \mathrm{s}^{-1} \times \mathrm{cm}^{-2}\right)$ for single-crystal and multilayer composite detectors ZWO $\left(\mathrm{ZnWO}_{4}\right), \mathrm{CWO}\left(\mathrm{CdWO}_{4}\right), \mathrm{BGO}(\mathrm{Bi} 4 \mathrm{Ge} 3 \mathrm{O} 12$, composite). The measured response for ZWO detector was $\sim 64$ pulse/neutron, for $\mathrm{CWO} \sim 36 \mathrm{pulse} /$ neutron, for $\mathrm{BGO} \sim 0.44 \mathrm{pulse} /$ neutron. The detectors response was registered by a fast preamplifier with the operation speed of up to $500 \mathrm{MHz}$, based on high-speed operational amplifiers with voltage feedback. The statistical error of measurement for the neutron registration efficiency by the broadband channel made $7 \%$ for the detectors with the effective thickness of $\sim 40-50 \mathrm{~mm}$, which is due to the spherical geometry of the experiment. The formation of the detector response is affected by the following parameters of neutron reactions: cross section of inelastic and resonant scattering of scintillator nuclei, density of composite nuclei levels, resonance region width, lifetimes of long-lived states and their number. The measured values of the counting efficiency of fast neutrons registration are accounted for the fact that the inelastic scattering reaction for some nuclei is the starting point that triggers the cascade process of the nuclear states discharge. The registration of the cascade of the discharge gamma-quanta, ranging from nanoseconds to a few microseconds, causes an increase in the detector counting efficiency and, as a consequence, an increase in the detector sensitivity to neutron detection. The observed increase in the counting efficiency of secondary gamma quanta is realized when the neutrons are slowed down in the detectors having sufficiently noticeable thickness and appropriate isotopic composition.
\end{abstract}

KEY WORDS: detector, fast neutrons, excited states, countable efficiency, density of nuclear levels

Creation of highly sensitive detectors for the neutron and gamma-neutron radiation monitoring systems is the issue of the day. The objective of this work is studying the response of single-crystal and multilayer composite detectors under their irradiation by fast neutrons, aimed at creation of compact and efficient detectors of neutron and gammaneutron radiation intended for control of the illegal transportation of fissile and radioactive materials. In [1, 2] it was shown that the mechanism of inelastic scattering $\left(n, n^{\prime} \gamma\right)$ can be used for registration of the fast neutrons by detector, in which heavy oxide scintillators are utilized as the working material [3-5]. Fast neutrons in this detector are registered by counting pulses induced by the secondary gamma quanta.

In the process of slowing down the fast neutrons in oxide detectors with the thickness of $4-5 \mathrm{~cm}$ and above, the resonance region energies $(\sim 1-100 \mathrm{keV})$ are achieved. In the case of elastic resonant scattering, the nuclei emit prompt gamma quanta, since the lifetime of the composite nucleus is short. At the inelastic resonance scattering $\left(n, n^{\prime} \gamma\right)_{\text {res }}$ the escaped neutron has a small energy and, consequently, a highly probability to be captured by the nuclei in ( $\mathrm{n}, \gamma$ ) reaction. Daughter compound nuclei with a short and mean lifetime of the states are excited. Thus, in the process of slowing down, the fast neutrons excite a chain of genetically bound nuclear states and generate gamma rays from $\left(n, n^{\prime} \gamma\right)$ and $\left(n, n^{\prime} \gamma\right)_{\text {res }}$ reactions $[6,7]$.

Thus, the inelastic scattering reaction $\left(n, n^{\prime} \gamma\right)$ is the starting point that triggers the cascade process of formation and decay of the excited nuclei states in the crystals under study.

If the lifetimes of nuclear states are in the range from nanoseconds to tens of microseconds, then the detector response registration causes an increase in the detector counting efficiency and, as a result, an increase in its sensitivity to gamma-neutron flux.

This paper presents the measurement data and the analysis of contributions of the conversion mechanisms during the fast neutrons slowing down to the genetically bound cascades of gamma-quanta from inelastic and resonant inelastic scattering of fast neutrons on the nuclei of single-crystal and multilayer oxide ZWO, BGO, CWO detectors.

\section{RESEARCH METHODS}

The fast neutrons response in the detectors under study is formed by gamma quanta scattered in the detector, and it should be noted, that the spectrum has no evident peculiarities and, in general, is a superposition of several exponents. In this case, it is very important to correctly determine the lower registration threshold of the detector under study.

To estimate the registration efficiency we used the parameter "counting" efficiency or "pulse/particle" i.e. the ratio of the detector counting rate from $1 \mathrm{~cm}^{2}$ to the number of particles captured by the detector on the area of $1 \mathrm{~cm}^{2}$ per $1 \mathrm{~s}$, (C) Volodymyr Ryzhikov, Gennadiy Onyshchenko, Ivan Yakymenko, Sergei Naydenov, Alexandr Opolonin,

Sergei Makhota, 2019 
i.e. pulse $\times \mathrm{s}^{-1} \times \mathrm{cm}^{-2} /$ neutron $\times \mathrm{s}^{-1} \times \mathrm{cm}^{-2}$. The choice of this parameter allows correct estimation of the sensitivity to neutrons of the detectors operating on the principle of registration of the secondary products, which are different from the incident particle.

In the process of scattering and slowing down in the detector material having linear dimensions $\sim 3-5 \mathrm{~cm}$ the energy of the fast neutrons decreases from $10 \mathrm{MeV}$ to several $\mathrm{keV}$ or less. This makes it possible to use for the detection purposes the mechanisms, which are specific for low-energy regions, and have high interaction cross sections and level densities, for example, resonant inelastic scattering, and which, ultimately produce the chains of gamma quanta.

The nuclear reaction analysis based on thermodynamic model [8] allows approximately estimating the average energy of the emitted neutron, the average excitation energy of the compound, and that of the daughter nuclei, which is equal to $\sim 1.5-3 \mathrm{MeV}$. This energy is quite sufficient to excite at least one lower energy level in the nuclei of medium and large atomic weight scintillators (for example, $\mathrm{W}, \mathrm{Zn}, \mathrm{Cd}, \mathrm{Bi}$ ), whose decay causes gamma quanta emission.

With the decay of nuclear states excited in reactions with neutrons, in addition to the prompt gamma quanta from $\left(\mathrm{n}, \mathrm{n}^{\prime} \gamma\right)$ reaction, the emission of the delayed gamma quanta from the compound nucleus $(\mathrm{A}+1, \mathrm{Z})$, the daughter nucleus $(\mathrm{A}, \mathrm{Z})$ and secondary neutrons capable to re-capture are possible [11].

The quanta in the lifetime range for the excited states from nanoseconds to tens of microseconds are of practical interest. It is the combination of the prompt and delayed quanta that forms genetically bound chains, which efficiently enhance the events statistics.

Radiometric characteristics of the single-crystal detectors ZWO, CWO and multi-layer composite detector BGO, irradiated by fast neutrons from ${ }^{239} \mathrm{Pu}-\mathrm{Be}$ source were measured using a broadband $(\Delta \mathrm{f}=500 \mathrm{MHz})$ counting channel.

The broadband channel efficiently registers the signals with the duration of $\sim 0.7 \mathrm{~ns}-1000 \mathrm{~ns}$ and amplitude of $>2 \mathrm{mV}$. The total dark noise of the photomultiplier tube (PMT) and the noise of electronics are $\sim 10 \mathrm{mV}$.

In this time domain the prompt gamma-quanta signals, arising in inelastic and resonant inelastic reactions of the neutron scattering, and signals of the nuclei long-lived nuclear states decay may be observed.

The structural scheme of the experiment in spherical geometry is shown in Fig. 1.

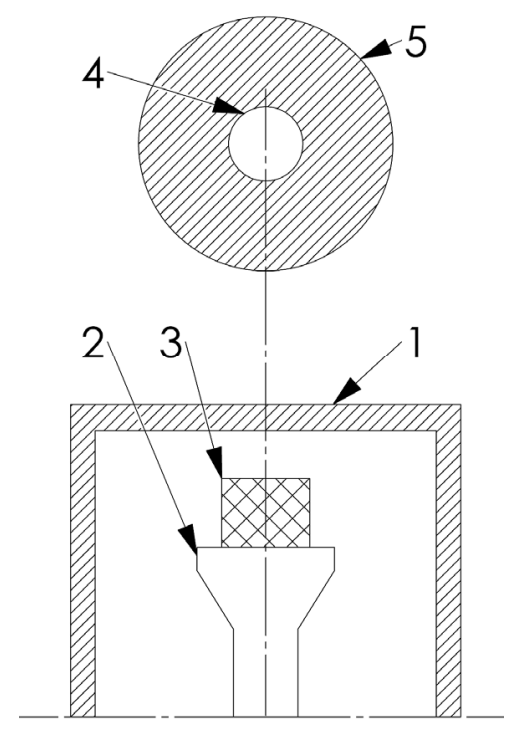

Fig. 1. Structural scheme for measuring the efficiency of fast neutrons registration in spherical geometry: $1-5 \mathrm{~mm}$ thick lead shield to attenuate the noise background in the low-energy region; 2 - photomultiplier R1307; 3 - scintillator under study; 4 - neutron source ${ }^{239} \mathrm{Pu}-\mathrm{Be} ; 5-\varnothing 100 \mathrm{~mm}$ lead ball, with $\varnothing 20 \times 50 \mathrm{~mm}$ well; detector - source distance - $1000 \mathrm{~mm}$.

In this work the "spherical" geometry was used (Fig. 2) [9]. In case the isotropic neutron source is surrounded by a thick spherically symmetric layer of the matter, that can only scatter the neutrons (elastically and inelastically), but not absorb them, the number of neutrons, emitted into outer space, will not change. Scattering in the beam directed to the detector (front hemisphere) is compensated for by scattering into the detector from other points of the ball (rear hemisphere). Due to the spherical symmetry of the entire device, the number of neutrons passing through every square centimeter of the spherical surface will also remain unchanged.

Lead spherical shield has practically no effect on the number of elastically and inelastically scattered neutrons, with the exception of neutrons absorbed in the lead ball due to the reaction of radiation capture (n, $\gamma$ ). Thus, the scattering ball does not change the neutron counting rate in the detector, and the spherical shield ball performs the function of attenuation of only gamma quanta, but not of the neutron flux, what, in fact, is necessary for the efficiency measurement technique. 
We can say that the scattering in the shield ball is compensated for by the experiment geometry. The compensation is carried out by the entire volume of the ball, especially, if the absorber thickness is insignificant, as compared to the distance between the source and the detector, and the ball shape is close to ideal.

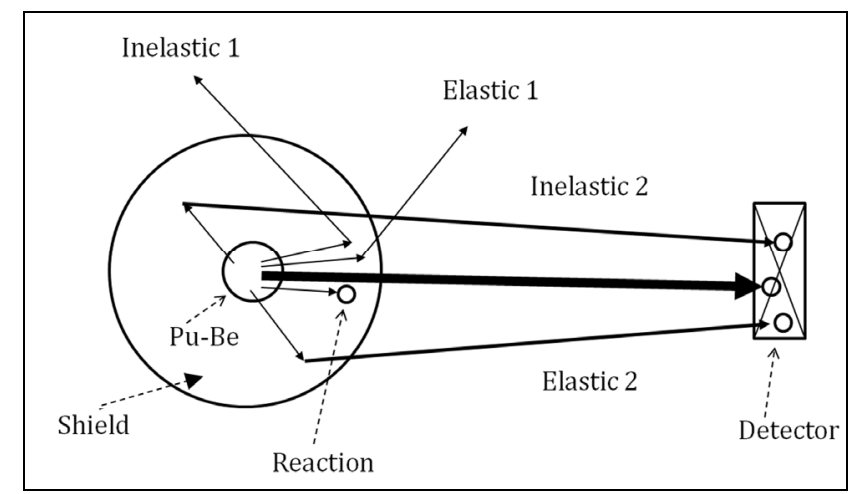

Fig. 2. Processes of fast neutrons scattering $(\rightarrow)$ and absorption $(\circ)$ in "spherical" geometry

One of the disadvantages of spherical geometry is an increase in the effective size of the neutron source and, as a result, the need to perform measurements at large distances $(\sim 1 \mathrm{~m})$ as compared to the "narrow" geometry, what also requires a more intensive source. The deviation from the law of inverse squares for the neutron source in the range of $1-1.2 \mathrm{~m}$ does not exceed 3\%, for the distance of $0.5 \mathrm{~m}$, the error increases to $30 \%$. Besides, the shape of the neutron spectrum undergoes some distortion.

Note, that if the counting rate is measured both with a ball and without it, then it is possible to determine the cross section for radiation capture reaction in the matter of the spherical sample. The coefficient of the neutron absorption in the shield sphere sample was measured for the concrete type of the neutron source and shield sphere ball of a certain diameter and chemical composition, the determined attenuation coefficient was used further in studies of scintillators of any size. The constancy of the absorption coefficient correction turns out to be the determining factor, if it is necessary to carry out accurate measurements with a large number of detectors of different size, for which it is difficult to take into account the attenuation factor in shadow geometry due to the significant effect of the accumulation factor. In addition to improving the measurement accuracy by eliminating the influence of the neutron accumulation factor, the spherical geometry also allowed to reduce the effect of the scattered gamma quanta excited by a neutron source in the walls of the laboratory room. As a source of neutrons the ${ }^{239} \mathrm{Pu}$-Be source with the neutron flux of $0.95 \times 10^{5}$ neutron $\times \mathrm{s}^{-1}$ was used. The source was placed inside $\varnothing 100 \mathrm{~mm}$ lead ball, with $\varnothing 20 \mathrm{~mm}$ well. The size of the source: $\varnothing 20 \times 30 \mathrm{~mm}$. The lead ball, besides the main task to reduce the effect of the accumulation factor in the material of the ball, at the same time attenuates the accompanying gamma radiation from ${ }^{239} \mathrm{Pu}-\mathrm{Be}$ source. In the neutron source there is an accompanying high-energy gamma radiation from the reactions: ${ }^{4} \mathrm{He}+{ }^{9} \mathrm{Be} \rightarrow{ }^{13} \mathrm{C}^{*} \rightarrow{ }^{12} \mathrm{C}^{*}+\mathrm{n} \rightarrow{ }^{12} \mathrm{C}+\mathrm{n}+\gamma$ $\left(\mathrm{E}_{\gamma}=4.43 \mathrm{MeV}\right),{ }^{13} \mathrm{C}^{*}>{ }^{13} \mathrm{C}+\gamma\left(\mathrm{E}_{\gamma}=3.68 \mathrm{MeV}\right)$.

The correction to the efficiency of fast neutrons detection by registering gamma rays with the energy $\mathrm{E}_{\gamma}=4.43 \mathrm{MeV}$ for the ZWO oxide scintillator with a size $\varnothing 56 \mathrm{x} 40 \mathrm{~mm}$ made $\sim 0.08$. In this case, the $\gamma / \mathrm{n}$ ratio for ${ }^{239} \mathrm{Pu}$-Be source was taken equal to 0.71 [10], the absorption of gamma quanta with the energy of $4.43 \mathrm{MeV}$ in $40 \mathrm{~mm}$ thick lead was $\sim 0.15$, the absorption efficiency of gamma quanta with the energy of $4.43 \mathrm{MeV}$ in ZWO with a thickness of $50 \mathrm{~mm}$ was $\sim 0.8$.

The correction to the fast neutrons absorption in the shield lead ball subject to the radiative capture reaction $(\mathrm{n}, \gamma)$ was determined experimentally using ${ }^{6} \mathrm{LiI}(\mathrm{Eu})$ detector and made $\sim 2.5 \%$. The size of ${ }^{6} \mathrm{LiI}(\mathrm{Eu})$ scintillator was: $\varnothing 15 \times 10 \mathrm{~mm},{ }^{6} \mathrm{Li}$ enrichment was $96 \%$. The thermal peak $(\alpha+\mathrm{t})$ for ${ }^{6} \mathrm{LiI}(\mathrm{Eu})$ had the gamma equivalent of $3.98 \mathrm{MeV}$, fast neutrons were registered in the energy range of $3.98 \mathrm{MeV} \div 10 \mathrm{MeV}$. The correction for the gamma quanta with energy $\mathrm{E}=4.43 \mathrm{MeV}$ was taken into account.

The contribution of the scattered fast neutrons from the walls of the laboratory room did not exceed $3 \%$. The correction was determined using ${ }^{6} \mathrm{LiI}(\mathrm{Eu})$ detector by measuring the deviation from the law if inverse squares when registering the fast neutrons. The contribution of the scattered gamma radiation in the range of "source-detector" distance $\mathrm{R}=1 \div 2 \mathrm{~m}$ did not exceed $\sim 1 \%$. The correction was determined by measuring the deviation from the law of inverse squares when registering ${ }^{137} \mathrm{Cs}$ quanta.

An additional lead shield, $5 \mathrm{~mm}$ thick, served as a shield against the background gamma radiation. The coefficient of the background attenuation by $5 \mathrm{~mm}$ thick lead in the range of $10 \mathrm{keV}-150 \mathrm{keV}$ was $\sim 3$.

Multilayer composite detectors (Fig. 3) are of particular interest for detection of fast neutrons [12-14]. The energy registration efficiency (measured at the output pulse time $\tau=1 \mu \mathrm{s}$ ) for the fast neutrons, detected by composite detectors $100 \times 100 \times 40 \mathrm{~mm}$ in size, turned out to be comparable with that for the single-crystal detectors $\sim 10 \times 10 \times 10 \mathrm{~mm}$ in size [5], what allows using them to create large-size neutron detectors. 


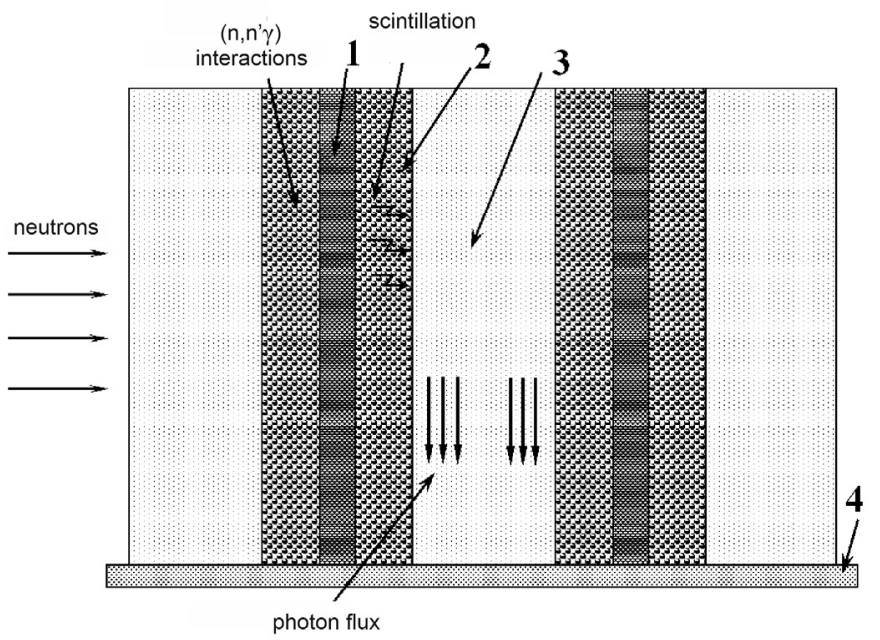

Fig. 3. The structure of the composite multilayer detector

1 - reflector; 2 - solution of scintillation granules ( $\varnothing \sim 300$ microns) in optical rubber; 3 - light guide, $\varnothing 5 \mathrm{~mm}$;

4 - photomultiplier tube window.

The statistical error of the neutron detection efficiency measurement by the broadband channel was $7 \%$ for the detectors with an effective thickness of $\sim 40 \mathrm{~mm}$. The time of the data accumulation was 5 exposures 20 minutes each at the source irradiation and the same values for the background accumulation.

Fig. 4 shows a block diagram of the measuring channels, which comprises Hamamatsu R1307 photomultiplier with the channel baseline noise level of $5 \mathrm{mV}$ at the photomultiplier voltage of $1100 \mathrm{~V}$ and a low-noise broadband amplifier [6, 7]. As the major recorder a pulse counter with bandwidth $\Delta \mathrm{f} \sim 200 \mathrm{MHz}$ was used. The linear spectrometric amplifier with the output pulse time $\tau=1 \mu$ s and Wilkinson analog-digital converter (ADC) with 2048 channels present an auxiliary channel, which serves to control the registration threshold.

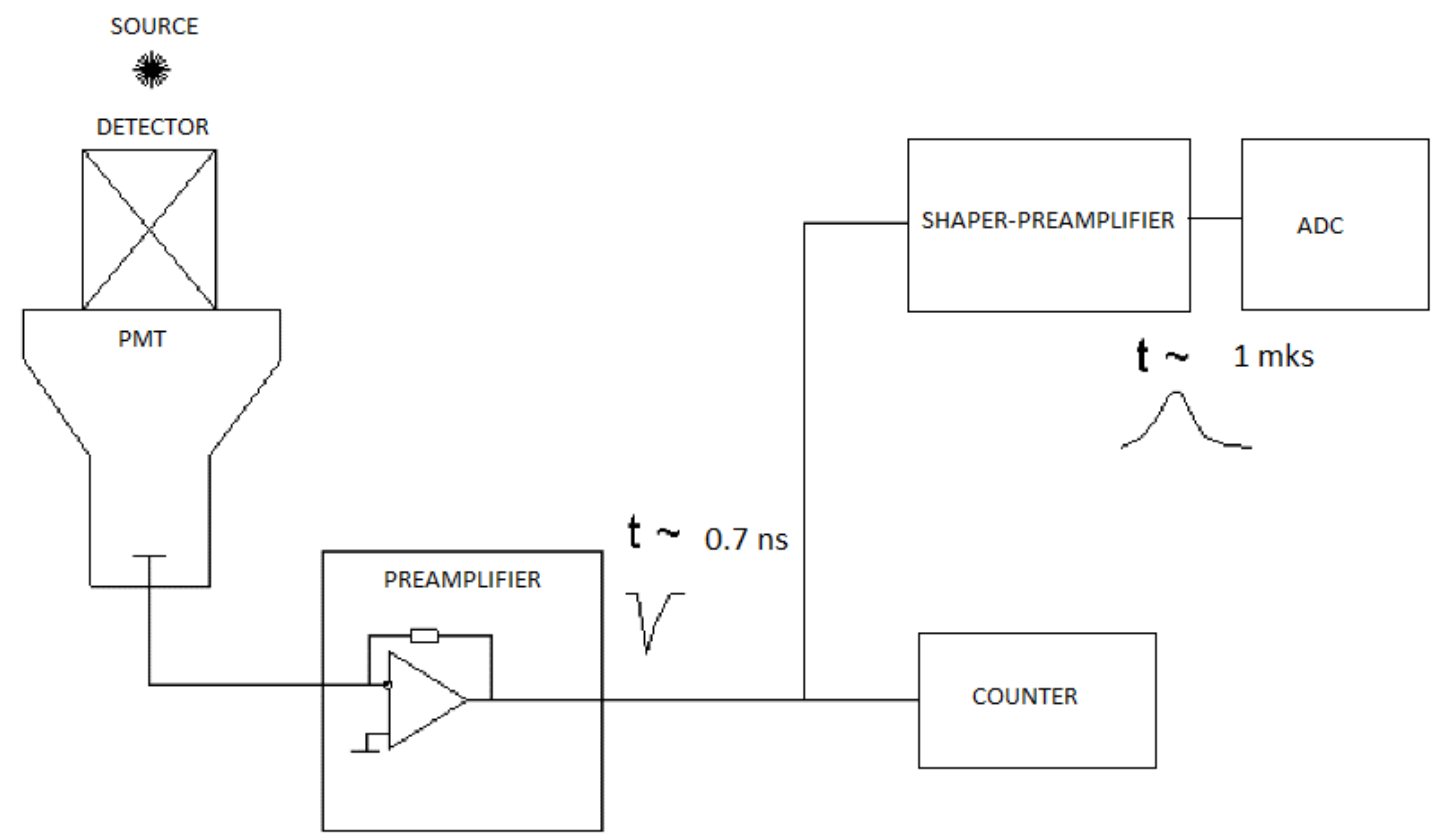

Fig. 4. Structural diagram of the measuring channels

Fig. 5 shows the circuit of the broadband pulse amplifier used to amplify the response signals from the detector. The proper rise time of the amplifier is $0.7 \mathrm{~ns}(\Delta \mathrm{f} \sim 500 \mathrm{MHz})$, the first stage is made according to the transimpedance amplifier circuit (current-to-voltage converter), the total amplification factor for the next 5 stages makes at least 32, the baseline noise in the absence of PMT is $5 \mathrm{mV}$, the baseline noise with the connected photomultiplier is $10 \mathrm{mV}$, active elements "Analog Devices 4817" are used.

Fig. 6 shows the signal shapes in the broadband ( $\tau=7 \mathrm{~ns}$, with PMT taken into account, the upper figure) and in the narrowband ( $\tau=1 \mu \mathrm{s}$, the lower figure) channels when the fast neutrons are detected by ZWO.

Fig. 7 shows the counting characteristic of the broadband channel $(\tau=7 \mathrm{~ns})$ as a function of the registration threshold. The operating point of the measurements corresponded to the registration threshold of $\sim 10 \mathrm{mV}$. 


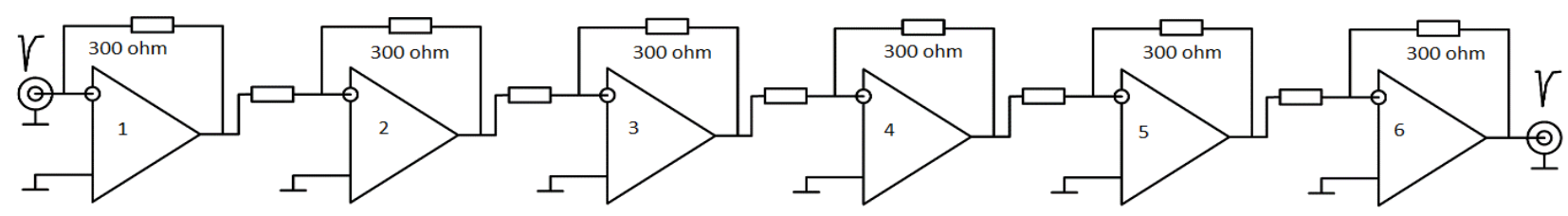

Fig. 5. Circuit of the broadband pulse amplifier.

Op1-Op6 - Analog Devices 4817. The value of the input resistors Op2-Op6 in the circuits of inverted inputs is 150 Ohms.

Fig. 8 represents on a logarithmic scale the hardware spectrum, which is registered by a narrow-band channel $(\tau=1 \mu \mathrm{s})$ in the process of interaction of the fast neutrons from ${ }^{239} \mathrm{Pu}$-Be source with ZWO detector. In the left part of the figure we can see the right-hand slope of the PMT noise distribution (exponent 1), which gradually passes into the region of the detector desired signal (exponent 2).

The starting-point of the desired signal area is in the 160-th channel, what corresponds to $\sim 10 \mathrm{mV}$. The peak observed at the beginning of the scale is the right-hand slope of the PMT dark pulses distribution.

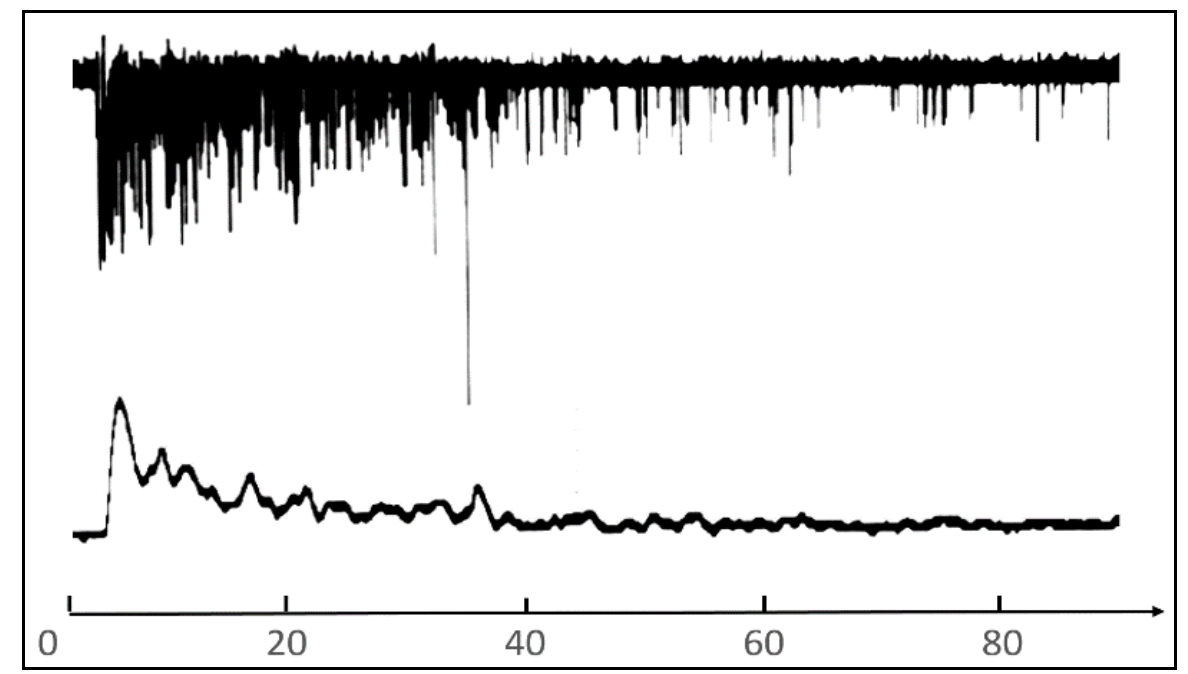

Fig. 6. Wave shapes for ZWO detector in the broadband ( $\tau=7 \mathrm{~ns}$, the upper figure) and narrowband ( $\tau=1 \mu \mathrm{s}$, the lower figure) channel. X axis - time, $\mu$ s.

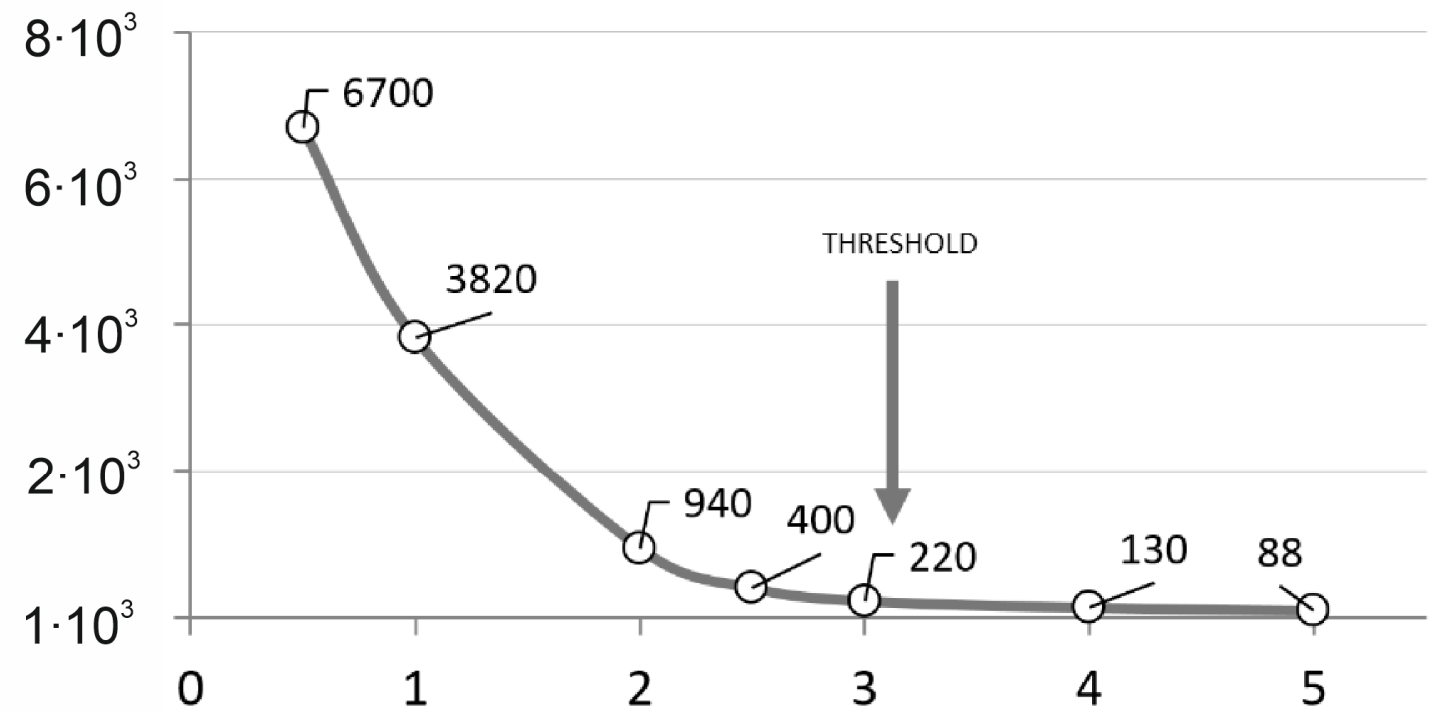

Fig. 7. The counting characteristic of the broadband channel as a function of the registration threshold. $\mathrm{X}$ axis is the registration threshold in relative units, $\mathrm{Y}$ axis is the counting rate, pulse/sec. 


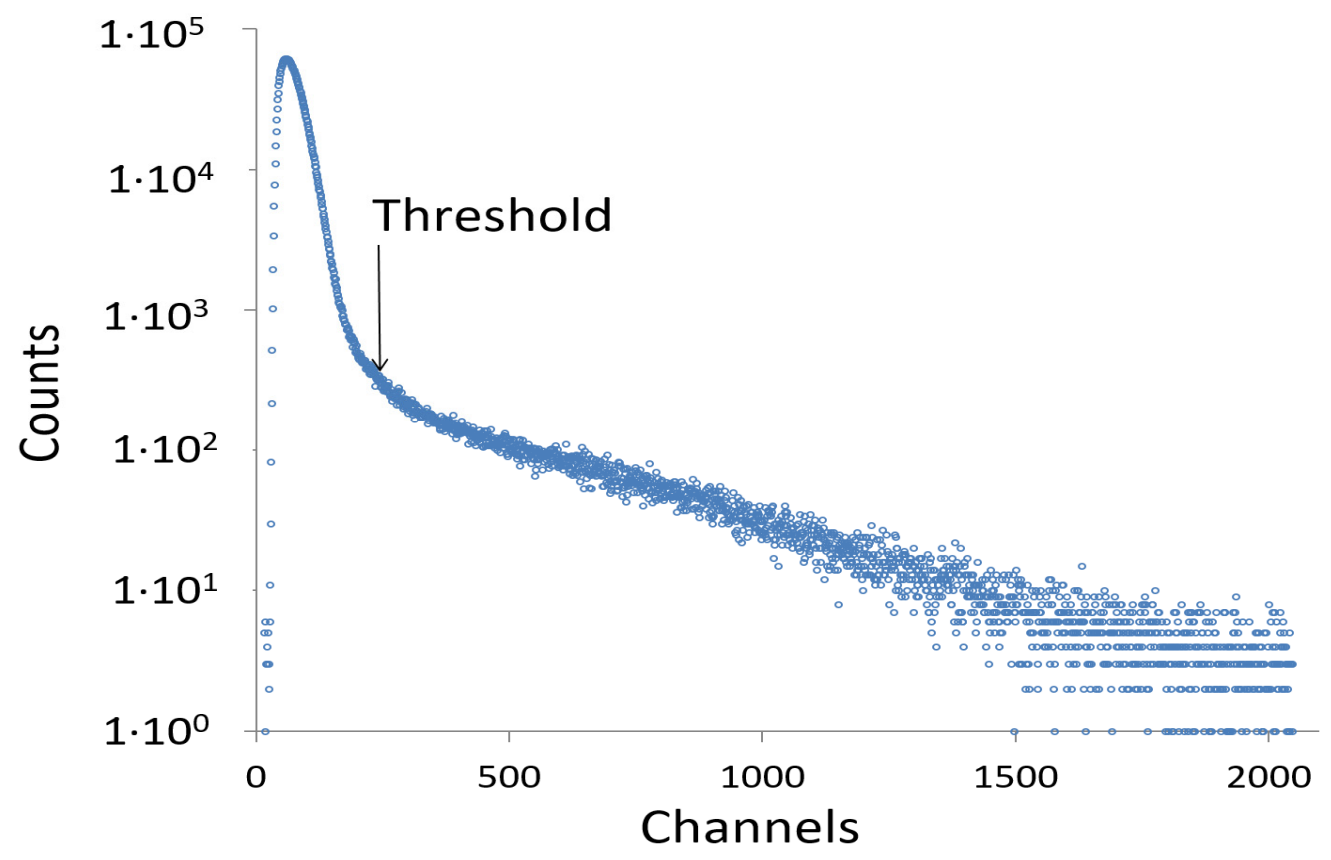

Fig. 8. The hardware spectrum on a logarithmic scale, which is registered in the narrowband channel $(\tau=1 \mu \mathrm{s})$ at the interaction of fast neutrons from ${ }^{239} \mathrm{Pu}$-Be source with ZWO detector. The scintillator size is $\varnothing 56 \times 40 \mathrm{~mm}^{3}$. The position of the vertical arrow corresponds to the threshold $\sim 10 \mathrm{mV}$. X axis is the channel number. $\mathrm{Y}$ axis is the number of pulses.

\section{THE RESULTS}

In this work the experimental values of the response to the fast neutrons of ${ }^{239} \mathrm{Pu}-\mathrm{Be}$ source for the detectors: BGO (multilayer) - 0.44 pulse/neutron, ZWO (single-crystal) - 64 pulse/neutron, CWO (single-crystal) - 36 pulse/neutron are obtained (Fig. 9). The data are represented in units "pulse/neutron" (pulse $\left.\times \mathrm{s}^{-1} \times \mathrm{cm}^{-2}\right) /\left(\right.$ neutron $\left.\times \mathrm{s}^{-1} \times \mathrm{cm}^{-2}\right)$, counting efficiency), i.e. as a ratio of the rate of counting, taken from $1 \mathrm{~cm}^{2}$ of the detector input window, to the neutron flux density.

\section{Counting efficiency}

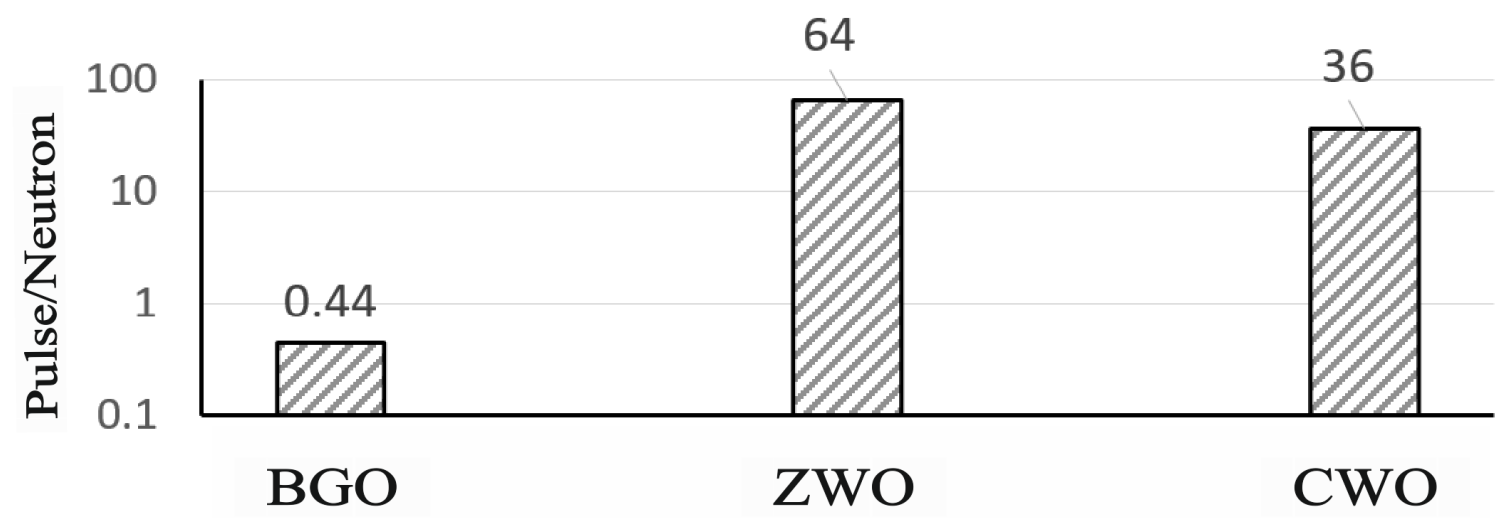

Fig. 9. Response to fast neutrons for the detectors: BGO (multilayer) - 0.44 pulse/neutron, ZWO (single-crystal) - 64 pulse/neutron, CWO (single-crystal) - 36 pulse/neutron. The ordinate axis is the ratio of the rate of counting, taken from $1 \mathrm{~cm}^{2}$ of the detector input window, to the neutron flux density (pulse/neutron).

The obtained results for the counting efficiency of fast neutrons registration can be explained, firstly, by registration of prompt gamma quanta from the reactions of inelastic scattering $\left(\mathrm{n}, \mathrm{n}^{\prime} \gamma\right)_{i n}$, elastic and inelastic resonant scattering, and, secondly, by registration of genetically bound decay quanta of mean- and long-lived states of excitation nuclei from the reactions of inelastic scattering, elastic and inelastic resonant scattering and resonant radiation capture. This is contributed to by the use, as a fast preamplifier, the current-to-voltage converter with the operating frequency of $500 \mathrm{MHz}(\tau=0.7 \mathrm{~ns})$. 
It should be noted that the registration efficiency of the composite detectors in the counting mode proved to be comparable with that of single-crystal detectors when operating in the spectrometric mode [5]. This indicates to the possibility of creating fast neutron composite detectors of considerable size and high sensitivity as an alternative to He-3 counters.

In this work the experimental values of the response to the fast neutrons from ${ }^{239} \mathrm{Pu}-\mathrm{Be}$ source for $\mathrm{BGO}, \mathrm{ZWO}$ and CWO detectors were obtained. A significant increase in the counting efficiency of fast neutrons registration for ZWO and CWO detectors was found out. At that, the efficiency of fast neutrons detection by the multilayer composite detector BGO turned out to be comparable with that of the single-crystal detectors, when operating in the spectrometric mode [5].

The experimental results can be explained by registration of a significant number of cascade gamma-quanta induced by the neutron reactions with scintillator nuclei during the neutrons slowing-down in the detector material. In reactions with neutrons the cascades of secondary gamma quanta, which are genetically bound with the primary inelastic scattering neutron, emitted during the decay of the excited nuclear states, may be produced.

The parameters affecting the increase of the efficiency of fast neutrons detection during their slowing down in the matter of the detectors under study are as follows: inelastic scattering cross section, cross sections in the resonance region, width of the resonance region, density of nuclear levels of compound nuclei [11], lifetime and energy of the excited levels and their number.

It was the use of the fast operation channel, that increased the counting efficiency by about two orders of magnitude for gamma quanta of the short-lived nuclear states $(\sim 1-100 \mathrm{~ns})$ by ZWO, CWO single-crystal detectors, as compared to the registration method, which utilizes the spectrometric registration mode, in which a significant suppression of response pulses from the short-lived nuclear states is observed.

Thus, the application of the counting mode for registration of the response of the oxide scintillators allows creating the detectors alternative to the existing ${ }^{3} \mathrm{He}$ counters for the radiation fields monitoring.

\section{ACKNOWLEDGMENTS}

The authors are indebted to Mrs. G.E. Vetrova for assistance in preparing the English version of this paper.

\section{ORCID IDs}

Volodymyr Ryzhikov@https://orcid.org/0000-0002-2833-2774, Gennadiy Onyshchenko@https://orcid.org/0000-0001-6945-8413, Ivan Yakymenko 1 https://orcid.org/0000-0002-0194-837, Sergei Naydenov@ https://orcid.org/0000-0002-5585-763X,

\section{REFERENCES}

[1]. M. Anelli, G. Battistoni, S. Bertolucci, C. Bini, P. Branchini, C. Curceanu, G. De Zorzi, A. Di Domenico, B. Di Micco, A. Ferrari, P. Gauzzi, S. Giovannella, F. Happacher, M. Iliescu, M. Martini, S. Miscetti, F. Nguyen, A. Passeri, A. Prokofiev, P. Sala, B. Sciascia and F. Sirghi, Nuclear Instruments and Methods in Physics Research A, 581, 368-372 (2007), doi: 10.1016/j.nima.2007.08.005.

[2]. L.L. Nagornaya, V.D. Ryzhikov, B.V. Grinyov, L.A. Piven', G.M. Onyshchenko and E.K. Lysetska, Abstracts IEEE Nuclear Science Symposium, (Drezden, Germany, 2008).

[3]. B. Grynyov, V. Ryzhikov, L. Nagornaya, G. Onishcenko and L. Piven', Patent of USA. US 8.058.624 B2 (15 November 2011).

[4]. V.D. Ryzhikov, B.V. Grinyov, G.M. Onyshchenko, L.A. Piven, O.K. Lysetska, O.D. Opolonin, S.A. Kostioukevitch, and C.F. Smith; Proceedings Volume 9213, Hard X-Ray, Gamma-Ray, and Neutron Detector Physics XVI, 92131B (San Diego, California, 2014), doi: 10.1117/12.2058185.

[5]. V.D. Ryzhikov, S.V. Naydenov, G.M. Onyshchenko, L.A. Piven, T. Pochet and C.F. Smith, Nuclear Instruments and Methods in Physics Research Section A: Accelerators, Spectrometers, Detectors and Associated Equipment, 903, 287-296 (2018), doi: 10.1016/j.nima.2018.06.074.

[6]. I. Yakymenko, B. Grinyov, V. Ryzhikov, G. Onyshchenko, S. Naydenov, O. Opolonin and S. Makhota, Sixth International Conference "Engineering of scintillation materials and radiation technologies ISMART", (Minsk, 2018), pp. 46.

[7]. V.D. Ryzhikov, G.M. Onishenko, I.I. Yakimenko, S.V. Najdenov, A.D. Opolonin and S.V. Mahota, XVII конференция по физике высоких энергий и ядерной физике [XVII Conference on High Energy Physics and Nuclear Physics], (NSC "KIPT", Kharkiv, 2019), pp. 96.

[8]. J.M. Blatt and V.F. Weisskopf, Theoretical Nuclear Physics, (2010).

[9]. A.I. Abramov, Ju.A. Kazanskij and E.S. Matusevich, Основы экспериментальных методов ядерной физики [Fипdатепtals of experimental methods in nuclear physics], (Energoatomizdat, Moscow, 1985), pp. 488.

[10].G. Venkataraman, Dayashankar and J.S. Jayakar, Nuclear Instruments and Methods, 82, 49-50, (1970), doi: 10.1016/0029$554 X(70) 90323-X$.

[11]. T. Egidy and D. Bucurescu, Physical Review C, 72, 044311 (2005), doi: 10.1103/PhysRevC.72.044311.

[12]. V.D. Ryzhikov, S.V. Naydenov, T. Pochet, G.M. Onyshchenko, L.A. Piven and C.F. Smith, IEEE Trans. Nuclear Sciences, 65(9), 2547-2553 (2018), doi: 10.1109/TNS.2018.2825642.

[13].V.D. Rizhikov, V.O. Litichevskij, G.M. Onishchenko, L.O. Piven et al, Patent UA 109524 C2, (25 August 2015), (in Ukrainian).

[14]. V.D. Ryzhikov, S.V. Naydenov, T. Pochet, G.M. Onyshchenko, L.A. Piven and C.F. Smith, EPJ Web of Conferences, 170(5), 07010 (2018), doi: 10.1051/epjconf/201817007010. 


\section{ДОСЛІДЖЕННЯ ВІДГУКУ МОНОКРИСТАЛІЧНИХ ТА БАГАТОШАРОВИХ ДЕТЕКТОРІВ НА ОПРОМІНЕННЯ} ШВИДКИМИ НЕЙТРОНАМИ

В.Д. Рижиков ${ }^{1}$, Г.М. Онищенко ${ }^{1,2}$, І.І. Якименко ${ }^{2}$, С.В. Найденов ${ }^{3,1}$, О.Д. Ополонін ${ }^{1}$, С.В. Махота ${ }^{1}$

'Інститут Сцинтилячійнихих Матеріалів, НТЦ “Інститут Монокристалів” НАН Украӥни пр. Науки, 60, 61001, Харків, Украӥна

${ }^{2}$ Харківський Національний Університет імені В. Н. Каразіна

пл. Свободи, 4, Харків, 61022, Украӥна

${ }^{3}$ Інститут Монокристалів, НТЦ “Інститут Монокристалів”, НАН Украӥни пр. Науки, 60, 61001, Харків, Украӥна

Метою цієї роботи було вивчення відгуку детекторів на основі оксидних сцинтиляторів при опроміненні потоком швидких нейтронів джерела ${ }^{239} \mathrm{Pu}$-Ве шляхом реєстрації імпульсів ФЕП. У процесі досліджень вимірювалася лічильна ефективність детекторів в одиницях (імпульс $\left.\times \mathrm{c}^{-1} \times \mathrm{cm}^{-2}\right) /\left(\right.$ нейтрон $\left.\times \mathrm{c}^{-1} \times \mathrm{cm}^{-2}\right)$ для монокристалічних і багатошарових композитних детекторів $\mathrm{ZWO}\left(\mathrm{ZnWO}_{4}\right), \mathrm{CWO}\left(\mathrm{CdWO}_{4}\right), \mathrm{BGO}\left(\mathrm{Bi}_{4} \mathrm{Ge}_{3} \mathrm{O}_{12}\right)$. Виміряний відгук для детектора $\mathrm{ZWO}$ склав 64 імпульс/нейтрон, для CWO 36 імпульс/нейтрон, для $\mathrm{BGO} \sim 0.44$ імпульс/нейтрон. Відгук детекторів реєструвався широкосмуговим передпідсилювачем з швидкодією до 500 МГц, виконаним із застосуванням швидкодіючих операційних підсилювачів зі зворотним зв'язком по напрузі. Статистична похибка вимірювань значення ефективності реєстрації нейтронів широкосмуговим трактом становила 7\% для детекторів 3 ефективною товщиною $\sim 40-50$ мм, що обумовлюється використанням сферичної геометрії експерименту. На формування відгуку детектора впливають наступні параметри нейтронних реакцій: перерізи непружного і резонансного розсіювання ядер сцинтиляторів, щільність рівнів складених ядер, ширина резонансної області, час життя ядерних станів і їх кількість. Виміряні значення лічильної ефективності реєстрації швидких нейтронів пояснюються тим, що реакція непружного розсіювання для деяких ядер є відправною точкою, що ініціює каскадний процес створення та розрядки ядерних станів. Реєстрація каскаду розрядних гамма-квантів, починаючи від наносекунд до одиниць мікросекунд, викликає збільшення ефективності реєстрації детектора і, як наслідок, збільшення чутливості детектора до детектування нейтронів. Спостережуване збільшення лічильної ефективності вторинних гаммаквантів реалізується при уповільненні нейтронів в детекторах досить помітною товщини і відповідного ізотопного складу.

КЛЮЧОВІ СЛОВА: детектор, швидкі нейтрони, збуджені стани, лічильна ефективність, щільність ядерних рівнів

\section{ИССЛЕДОВАНИЕ ОТКЛИКА МОНОКРИСТАЛЛИЧЕСКИХ И МНОГОСЛОЙНЫХ КОМПОЗИТНЫХ ДЕТЕКТОРОВ ПРИ ОБЛУЧЕНИИ БЫСТРЫМИ НЕЙТРОНАМИ}

В.Д. Рыжиков ${ }^{1}$, Г.М. Онищенко ${ }^{1,2}$, И.И. Якименко ${ }^{2}$ С.В. Найденов ${ }^{3,1}$, А.Д. Ополонин ${ }^{1}$, С.В. Махота ${ }^{1}$

${ }^{1}$ Институт Сцинтилляционных Материалов, НТЦ “Институт Монокристаллов" НАН Украины

пр. Науки, 60, 61001, Харьков, Украина

${ }^{2}$ Харьковский Национальный Университет имени В.Н. Каразина

пл. Свободы, 4, Харьков, 61022, Украина

${ }^{3}$ Институт Монокристаллов, НТЦ “Институт Монокристаллов”, НАН Украиньь пр. Науки, 60, 61001, Харьков, Украина

Целью настоящей работы являлось исследование отклика детекторов на основе оксидных сцинтилляторов при облучении потоком быстрых нейтронов источника ${ }^{239} \mathrm{Pu}-\mathrm{Be}$ путем регистрации импульсов ФЭУ. В процессе исследований измерялась счетная эффективность детекторов в единицах (импульс $\left.\times \mathrm{c}^{-1} \times \mathrm{cm}^{-2}\right) /\left(\right.$ нейтрон $\left.\times \mathrm{c}^{-1} \times \mathrm{cm}^{-2}\right)$ для монокристаллических и многослойных композитных детекторов ZWO $\left(\mathrm{ZnWO}_{4}\right), \mathrm{CWO}\left(\mathrm{CdWO}_{4}\right), \mathrm{BGO}\left(\mathrm{Bi}_{4} \mathrm{Ge}_{3} \mathrm{O}_{12}\right)$. Измеренный отклик для детектора ZWO составил $\sim 64$ импульс/нейтрон, для CWO $\sim 36$ импульс/нейтрон, для BGO $\sim 0.44$ импульс/нейтрон. Отклик детекторов регистрировался широкополосным предварительным усилителем с быстродействием до 500 МГц, выполненным на быстродействующих операционных усилителях с обратной связью по напряжению. Статистическая погрешность измерений значения эффективности регистрации нейтронов широкополосным трактом составляла $7 \%$ для детекторов с эффективной толщиной $\sim$ 40-50 мм, что обуславливается использованием сферической геометрии эксперимента. На формирование отклика детектора оказывают влияние такие параметры реакций с нейтронами, как величины сечения неупругого и резонансного рассеяния ядер сцинтилляторов, плотность ядерных уровней составных ядер, ширина резонансной области, времена жизни изомерных состояний, их количество. Измеренные значения счетной эффективности регистрации быстрых нейтронов объясняются тем фактором, что реакция неупругого рассеяния является стартовым процессом, который запускает каскадный процесс разрядки ядерных изомерных состояний. Регистрация каскада гаммаквантов разрядки в интервале от единиц наносекунд до единиц микросекунд приводит к увеличению счетной эффективности детектора и, как следствие, к повышению чувствительности детектора к обнаружению нейтронов. Наблюдаемое увеличение счетной эффективности вторичных гамма-квантов реализуется при замедлении нейтронов в детекторах достаточно заметной толщины и подходящего изотопного состава.

КЛЮЧЕВЫЕ СЛОВА: детектор, быстрые нейтроны, возбужденные состояния, счетная эффективность, плотность ядерных уровней 